\title{
Liberation of Protein and Antioxidative Compound from Spent Coffee Ground Through Protein Hydrolysis
}

\author{
Noor Ariefandie Febrianto ${ }^{1 *}$ \\ ${ }^{1}$ Indonesian Coffee and Cocoa Research Institute, Jl. PB Sudirman No. 90, Jember 68118, East Java, Indonesia \\ ${ }^{*}$ Corresponding author: ariefandie@iccri.com \\ Received: 23 November 2017 / Accepted: 2 May 2018
}

\begin{abstract}
Spent coffee ground is a primary by-product obtained during soluble coffee processing and potential to be used as a high value product due to its protein content. The quite popular effort to utilize protein-contained material is to process it to hydrolysate which also possess antioxidant activity. This research was aimed to study the possibility of protein and antioxidative compound from spent coffee ground by means of enzymatic hydrolysis using crude papain enzymes. Crude papain was used in different concentration ranged from 2,4 and $6 \%$ to incubate the spent coffee grounds for 2, 3, and 4 hours and then analyzed for its protein content and its antioxidant activity. Response surface methodology was employed to study the tendency of the effect of incubation time and enzymes concentration towards hydrolysis results. The result showed that the use of crude papain was effective to liberate the protein and antioxidant compound from the spent coffee ground with its optimum condition utilized $6 \%$ of enzyme and 2 hours incubation time. At mentioned condition, it could extract up to $67.4 \%$ of the protein of the spent coffee ground and its hydrolysate possessed relatively high antioxidant activity.
\end{abstract}

Keywords: antioxidant, papaya, coffee ground, hydrolysate

\section{INTRODUCTION}

The concern of the effort to convert agricultural by-products into high value added product has become a great interest in agricultural studies. The production of proteinbased product is one of the most popular utilization of plant-based agriculture material. Protein hydrolysate is one of the hydrolysatebased product which can be produced from by-product that contain protein. Protein hydrolysate is defined as products of protein breakdown which resulted in smaller peptides of various sizes which can be achieved by means of chemical or biological process (Pasupuleti \& Braun, 2010). Protein hydrolysate usually is produced from low valuehigh protein content by-product such as fish, soy and whey. However, a previous report showed that the protein hydrolysate could be successfully produced from low protein content, materials such as rice bran (Hamada, 2000), Jatropa quarks' (Gallegos-Tintore et al., 2011), and sweet potato (Zhang et al., 2012). The most interesting characteristic of protein hydrolysate may be its antioxidant activity which may serve as natural sources of antioxidant in food. Je et al. $(2005 ; 2007)$ 
previously reported that hydrolyzed proteins from animal and plant sources have been found to possess antioxidant activity. Several amino acids, such as tyrosine, methionine, histidine, lysine and tryptophan, are generally thought to have antioxidant properties. Further, Amarowicz (2008) also mentioned that the peptides obtained after hydrolysis might inhibit degradation of lipid caused by oxidation in which tyrosine, histidine, methionine and tryptophan are considered as the main player responsible for the antioxidative capabilities of protein hydrolysate.

Acid or base hydrolysis and enzymatic hydrolysis are the common method to produce protein hydrolysate. As reported by Pasupuleti $\&$ Braun (2010), the use of enzymes in the making of protein hydrolysate provides significant advantages compared to acid or base-based processes. Not only enzymatic hydrolysis require a relatively small amount of enzymes that can be easily deactivated and relatively easily-controlled conditions of hydrolysis (temperature and $\mathrm{pH}$ ), selectivity characteristic of the enzyme also provide more specific result compared to that of acid and base hydrolysis. Among popular protease enzymes such as protamex, alcalase and falvourzyme (Herpandi et al., 2013; 2017; Karamac, 2016) or plant based enzymes such as papain (Hoyle \& Merrit, 1994; Shahidi et al., 1995) and animal sources (e.g., Pepsin (Viera et al., 1995) and chymotrypsin and trypsin (Simpson et al., 1998), papain is one of the protease enzymes that can be easilyfound and produced in Indonesia. The use of crude papain to produce protein hydrolysate will be advantageous since it is cheaper and easily available in Indonesia.

Papain belongs to cysteine protease enzyme (EC 3.4.22.2) which is generally found in papaya (Carica papaya). Papain is reported to have wide varieties of activities covering both exo and endopeptidases activity. Endopeptidase hydrolyze alphapeptide bond in protein and generally resulted in the relatively long chain of peptide, whereas exopeptidases require free $\mathrm{N}$-terminal amino group and/or C-terminal carboxyl group to perform proteolytic process and hydrolyze a bond not more than three residues from terminus to produce smaller peptides or amino acids. Rawlings et al. (2007) previously mentioned that the digestion of food proteins usually initiated by endopeptidases to generate new $\mathrm{N}$ - and $\mathrm{C}$ termini, and then it is continued by exopeptidases which utilize that product as a substrate to complete the proteolytic process. The occurrence of both of exopeptidase and endopeptidase will guarantee the complete performance of protein hydrolysis.

Spent coffee ground (SCG) is a notable by-product usually generated during coffee processing or during brewing process prior to consumption (Cruz et al., 2012). It is reported to contain large amount of beneficial compound such as fatty acids, amino acids, polyphenols, mineral and polysaccharides (Campos-Vega et al., 2015). A lot of interest has been addressed especially on the antioxidant compound of underutilized SCG in term of its antioxidant activity (Esquivel \& Jimenez, 2012). Several investigations have been carried out to extract those beneficial compounds by mean of solvent extraction (Murthy \& Naidu, 2012), and enzymatic hydrolysis (Esquivel \& Jimenez, 2012). However, there is still no report of the utilization of freshly made papain enzymes to extract the antioxidant compound from SCG, thus this research aimed to study the utilization of papain to extract antioxidative compound from spent coffee ground and to measure its antioxidative capability to determine optimum conditions of hydrolysis of the papain solution system. 


\section{MATERIALS AND METHODS}

The spent coffee ground was obtained from a coffee processing plant in Indonesian Coffee and Cocoa Research Institute (ICCRI) Jember, East Java. The sample used in this experiment was the spent coffee ground obtained during the extraction of coffee powder. The SCG was characterized with $7.95 \%$ of moisture content, $2.94 \%$ ash content, $19.05 \%$ of fat content and $19.5 \%$ (db) of protein content. The papain enzyme was prepared independently utilizing local papaya planted in Kaliwining Experimental Station, Jember, East Java. The research was conducted in Post-harvest laboratory of ICCRI, Jember

The experiment was carried out using face centered central composite design based on randomized, factorial design of response surface methodology (RSM) with five replications at the center points by two variables each trial (three levels of each variable). The independent variables were enzyme concentration (A), and hydrolysis time (B). The levels of variable were coded as $(-1,0,+1)$ in which the actual level of enzyme concentration ranged from $2,4,6 \%$ and actual level of hydrolysis time was ranged from 2, 3, and 4 hours.

The papain was prepared based on the method of Sani (2008) which is previously mentioned in Febrianto (2016). The activity of the enzyme was $1,080 \mathrm{MCU} / \mathrm{g}$. The characterization of spent coffee grounds was done by analyzing its moisture content, ash content, fat content and protein content. The analysis was carried out using the method listed in Indonesian National Standard (SNI 3747-2013) (BSN, 2014) and Kjeldahl method for protein analysis.

The hydrolysis of spent coffee ground were carried out using water diluted-papain powder. Spent coffee ground were diluted with distilled water in the ratio of spent coffee ground to water was 1 to 4 prior to the addition of enzymes solution. The spent coffee ground solution was then added either using $0.5 \mathrm{~N}$ sodium hydroxide or $0.5 \mathrm{~N}$ Hydrochloric acid to adjust the $\mathrm{pH}$ at the point of 6.5 (the optimum $\mathrm{pH}$ of papain). The solution was then homogenized and $5 \mathrm{~mL}$ of the solution was transferred into a test tube. The papain enzyme solution was then added in various concentrations as much as 2, 4, 6\% of spent coffee ground weight. The mixed solution was then incubated in waterbath set at the temperature of $70^{\circ} \mathrm{C}$ for 2,3 , and 4 hours. Every 30 minutes, the mixtures were stirred to homogenize. After the defined time of hydrolysis was reached, the test tube was then dipped in boiling water for 10 to 15 minutes to terminate the hydrolysis process by stopping the proteolytic activity of papain enzyme. The solution obtained was then centrifuged at 3,500 RPM for 15 minutes and then separated between the supernatant and the precipitate. The supernatan was then filtered using Whatman filter paper grade 93 until solid-free solution was obtained. This solution was then stored in a screw capped bottle and stored in $4^{\circ} \mathrm{C}$ until analyzed. This solution obtained from the hydrolysis process was then referred as SCG hydrolysate.

The protein content of the SCG hydrolysate solution was measured using the method of Lowry (Sudarmadji et al., 1997). The Lowry A reagent was prepared by diluting $2 \mathrm{~g}$ of $\mathrm{Na}_{2} \mathrm{CO}_{3}$ in $100 \mathrm{~mL}$ of 0,1 $\mathrm{N} \mathrm{NaOH}$. Lowry B reagent was prepared by diluting $0.5 \mathrm{~g}$ of $\mathrm{CuSO}_{4} .5 \mathrm{H}_{2} \mathrm{O}$ in $100 \mathrm{~mL}$ of $1 \%$ sodium potassium tartarate. The Lowry $\mathrm{C}$ reagent was prepared fresh prior to analysis by mixing $50 \mathrm{~mL}$ of Lowry A $+1 \mathrm{~mL}$ of Lowry B. As much as $0.1 \mathrm{~mL}$ 
hydrolysate solution was added to $8 \mathrm{~mL}$ of Lowry $\mathrm{C}$ reagent. The solution was then allowed to stand for 10 minutes prior to the addition of $1 \mathrm{~mL}$ Follin Ciocalteu reagent and then homogenized. The absorbance of the solution was then measured using a spectrophotometer (Perkin Elmer Lambda $35 \mathrm{UV} / \mathrm{V}$ is Spectrophotometer) using a wavelength of $600 \mathrm{~nm}$. The standard curve was prepared by using Bovine serum albumin in the concentration range of 0 to $3 \mathrm{mg} / \mathrm{mL}$.

Radical scavenging activity (RSA) analysis was performed based on the activity of the 2,2-diphenyl-1-picrylhydrazyl (DPPH). This analysis was carried out using the method of Kalantzakis et al. (2006) with some modification. The methanolic extract was prepared by diluting $0.1 \mathrm{~mL}$ of sample with $4.9 \mathrm{~mL}$ methanol. As much as $0.1 \mathrm{~mL}$ of the methanolic solution was then placed into a test tube and mixed with $4.9 \mathrm{~mL}$ DPPH solution $(0.1 \mathrm{mM}$ in methanol) then shaken vigorously. The solution was then placed in a dark place for 30 minutes. The absorbance of the sample mixture was then measured at $517 \mathrm{~nm}$ using a spectrophotometer (Perkin Elmer Lambda $35 \mathrm{UV} /$ Vis Spectrophotometer). RSA result was presented as 6-hydroxy-2,5,7,8-tetramethylchroman-2-carboxylic acid (trolox) equivalent.

Statistical analysis was carried out using Design Expert ${ }^{\circledR}$ version 7.0.0 (Stat-Ease, Inc., Minneapolis, MN, USA). The RSM model was performed at the $5 \%$ significance level in which $\mathrm{p}<0.05$ was considered as significant parameters and non-significant parameters $(p>0.05)$ were excluded. Pearson correlation analysis was done using SPSS software ver. 17.0 (IBM).

\section{RESULT AND DISCUSSION}

Our preliminary assessment of spent coffee ground showed that the protein content was quite high around $19.5 \%$ on dry bases. This was slightly higher compared to the calculation result of Febrianto (2013) which mentioned that spent coffee ground could contain $13.5 \%$ to $18.75 \%$ of protein (db). Compared to other study carried out by Apiwatanapiwat et al. (2009), the production of hydrolysate also successfully carried out using the physic nut cake with protein content of $18.98 \%$. On the material with lower protein content, the succeess of hydrolysis was also reported by Zarei et al., (2012) who used palm kernel cake (17.6\% protein content) as the substrate of the hydrolysis.

Summarized Anova of response surface analyses on protein content and the antioxidant activity showed that the responses followed the quadratic model (Table 1) with good coefficient of determination $\left(\mathrm{R}^{2}=0.918\right)$. It was also found that the protein content only affected by the papain enzym concentration. Protein content as analysed with Lowry method (Table 2) showed that the content varied from 10 to $13.14 \mathrm{mg} / \mathrm{mL}$ of SCG hydrolysate. Wu et al. (1998) previously mentioned that the incubation of protein material utilizing papain enzyme could resulted in water soluble amino acid/peptides. On the optimum condition of hydrolysis ( $6 \%$ and $4 \mathrm{~h}$ ), the soluble extractable protein was calculated for around $67.4 \%$ of total protein of the SCG. The enzyme concentration was only the significant factor means that the performance of the hydrolysis was independent to the time of hydrolysis. As shown in Figure 1, the addition of $6 \%$ enzymes with incubation time for 2 hours resulted in not significantly 
different result with that of 4 hours. The insignificancy of the time of incubation might be caused by slow proteolysis rate of the enzyme to degrade the protein resulted in not significant result obtained from 1 to 2 hours differences. Haslaniza et al. (2010) previously reported that the hydrolysis of protein from cockle meat could last for 48 hours to obtain signiicant different result from 24 hours incubation.

Table 1. Summarized Anova of spent coffee ground hydrolysate based on response surface analysis

\begin{tabular}{lcc}
\hline Parameter & Protein Content & Antioxidant activity \\
\hline Model & Quadratic (significant) & Quadratic (significant) \\
Lack of fit & Significant & Significant \\
$\mathrm{R}^{2}$ & 0.9180 & 0.9434 \\
Adjusted $\mathrm{R}^{2}$ & 0.8594 & 0.9029 \\
Equation (Actual level) & $\mathrm{Y}=14.6098-0.41 \mathrm{~A}$ & $\mathrm{Y}=5.0277+0.133 \mathrm{~A}-0.2215 \mathrm{AB}+0.052 \mathrm{~A}^{2}$ \\
Significant factor & $\mathrm{A}$ & $\mathrm{A}, \mathrm{AB}, \mathrm{A}^{2}$ \\
\hline
\end{tabular}

Table 2. Response of protein content and antioxidant activity of the hydrolysate in different hydrolysis treatments

\begin{tabular}{|c|c|c|c|c|c|}
\hline \multicolumn{4}{|c|}{ Enzymes concentration $(\%)$ Incubation time (hours) } & \multirow{2}{*}{$\begin{array}{c}\text { Antioxidant activity } \\
(\mathrm{TE} \mathrm{mM} / \mathrm{mL})\end{array}$} & \multirow{2}{*}{$\begin{array}{l}\text { Protein Content } \\
(\mathrm{mg} / \mathrm{mL})\end{array}$} \\
\hline Coded level a & Actual level A & Coded level b & Actual level B & & \\
\hline-1 & 2.00 & -1 & 2.00 & 5.55 & 10.15 \\
\hline 0 & 4.00 & -1 & 2.00 & 5.43 & 11.74 \\
\hline 1 & 6.00 & -1 & 2.00 & 6.04 & 12.38 \\
\hline-1 & 2.00 & 0 & 3.00 & 5.83 & 10.21 \\
\hline 0 & 4.00 & 0 & 3.00 & 5.47 & 10.68 \\
\hline 0 & 4.00 & 0 & 3.00 & 5.30 & 10.45 \\
\hline 0 & 4.00 & 0 & 3.00 & 5.51 & 10.58 \\
\hline 0 & 4.00 & 0 & 3.00 & 5.30 & 11.19 \\
\hline 0 & 4.00 & 0 & 3.00 & 5.31 & 10.52 \\
\hline 1 & 6.00 & 0 & 3.00 & 5.22 & 12.58 \\
\hline-1 & 2.00 & 1 & 4.00 & 6.19 & 10.00 \\
\hline 0 & 4.00 & 1 & 4.00 & 5.38 & 11.14 \\
\hline 1 & 6.00 & 1 & 4.00 & 4.91 & 13.14 \\
\hline
\end{tabular}
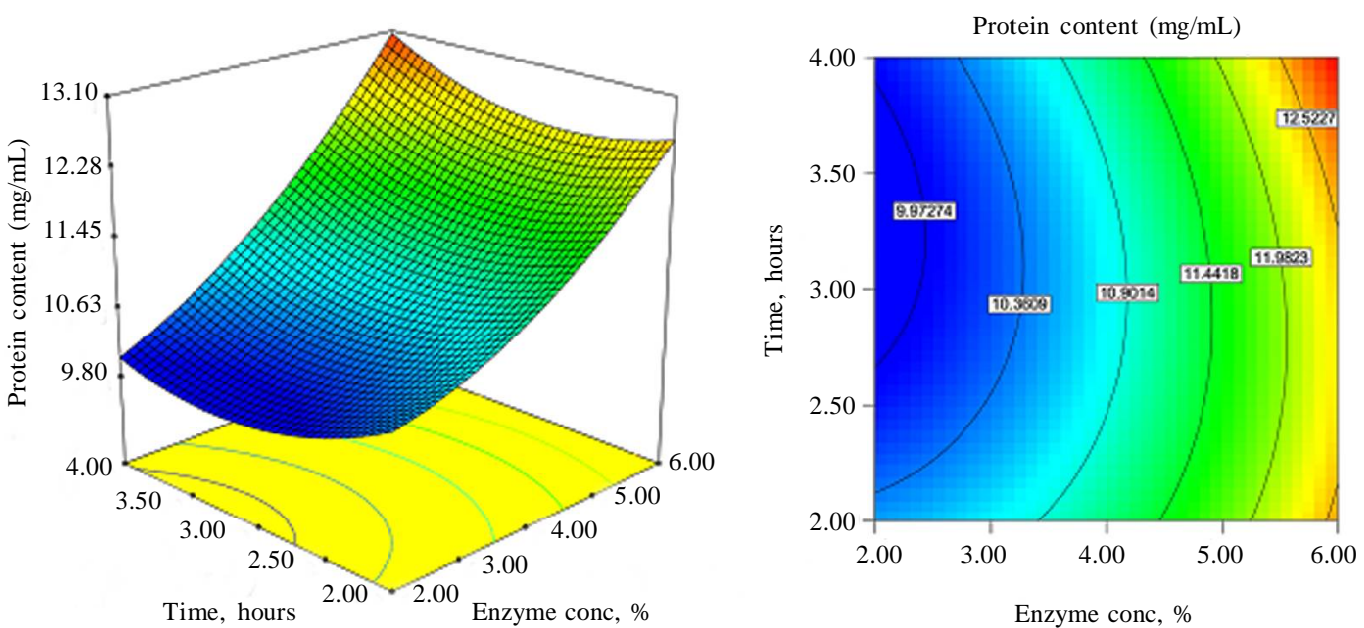

Figure 1. Response surface (left) and contour plot (right) of the effect of the enzyme concentration and incubation time on the protein content of spent coffee ground extract 
On the other hand, the use of enzyme with higher concentration resulted in significantly higher protein content obtained means that the protein degradation directly was actually happened. The insignificant effect of time along with significant effect of concentration might indicate that the degradable protein was available, but when it was accessible by the enzyme it takes longer time for the enzyme to connect with the next substrates. Ovissipour (2010) also mentioned that the decreasing hydrolysis activity might be caused by the limitation of enzyme activity by the formation of reaction products when occured during high degree of hydrolysis. It was also mentioned that other factors such as the enzyme inhabitation or enzyme deactivation might also contribute. However, the decrease in the concentration of peptide bonds available for hydrolysis supposedly not a deciding factor since the addition of more enzyme could resulted in higher protein content.

On the other hand, the antioxidant activity analysis showed that the antioxidant activity of SCG varied from 4.91 to $6.19 \mathrm{TE} \mathrm{mM} / \mathrm{mL}$. The responses of the treatment also complied with quadratic mathematical model with the coefficient of determination $\left(\mathrm{R}^{2}\right)$ was 0.943 .

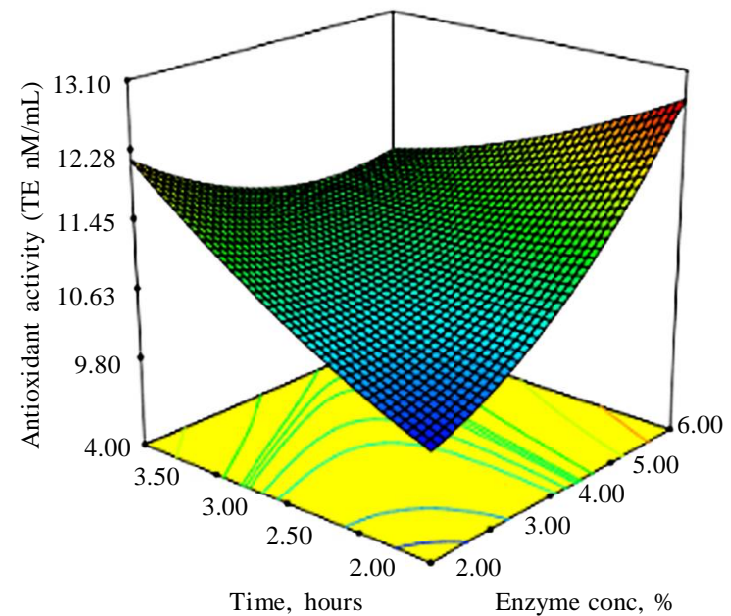

Enzyme concentration, its quadratic effect and its interaction with incubation time were found to be significant factor for the antioxidant activity of SCG hydrolysate.

As shown in Figure 2, the use of low concentration enzymes resulted in increasing trend of antioxidant activity of the SCG in prolonged incubation time. Otherwise, the opposite trend was observed in the SCG obtained from high concentration enzyme in prolonged incubation time. This result was sligthly different from the result of Centenaro et al. (2011) which mentioned that the use of higher concentration of enzyme resulted in higher antioxidant activity since higher degradation degree obtained from higher concentration of enzymes would resulted in increasing number of degraded protein (as peptide) and allowed the possibility to obtain higher number of hydrophobic peptides. However, the study was done in 3 hours of incubation time whereas in our study the incubation time was longer 4 hours. Jun et al. (2004) previously reported that the type of preotease enzymes used and the hydrolysis condition were significant factor which could determine the antioxidant activity of the hydrolysate.

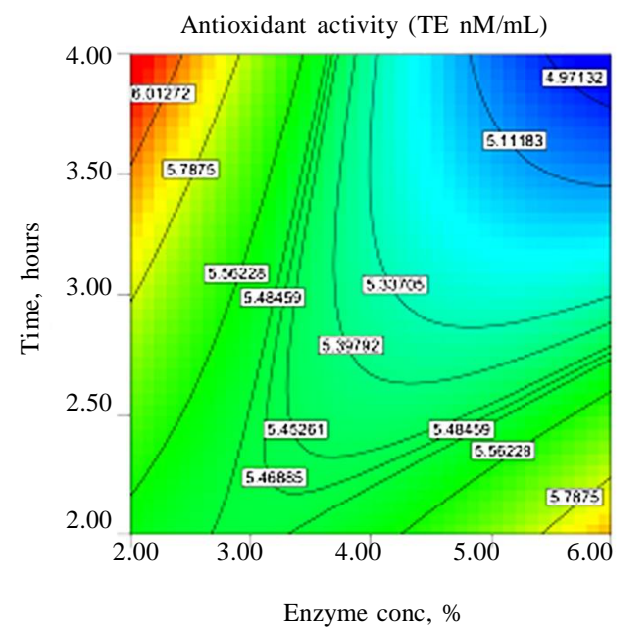

Figure 2. Response surface (left) and contour plot (right) of the effect of the enzyme concentration and incubation time on the antioxidant activity of spent coffee ground extract 
Rawlings et al. (2007) and Graf et al. (2004) mentioned that papain is categorized as endopeptidase, the type of protease that hydrolyze alpha-peptide bonds in polypeptide chain and tending to act away from the $\mathrm{N}$-terminus or $\mathrm{C}$-terminus. This type of enzymes tends to produce high molecular weight peptide rather than amino acid or oligopeptides (Chapot-Chartier, 2004; Dudley \& Steele, 2004). However, its is also mentioned previously by Uhlig (1998) and Tsuge et al. (1999) that papain belongs to papain superfamily which shows extensive proteolytic activities not only towards protein, but also to short-chain peptides, amino acids esters and amide links. Thus, papain could also shows exopeptidase activity and could also act as exopeptidases which utilize that product as a substrate to complete the proteolytic process resulting in amino acids or low molecular oligopeptides (Rawlings et al., 2007).

The size of hydrolysate also plays important role in antioxidant activity. As mentioned by Wu et al. (2003), small molecular weight hydrolysate showed lower antioxidant activity compared to that of hydrolysate with the size of $1400 \mathrm{Da}$. It was also in agreement with the result of Herpandi (2013) which found that hydrolysate from skipjack tuna, which were dominated with peptide in the range of molecular weight between 1000 to 3000 Da possessed higher antioxidant activity comparable to hydrolysate which is dominated with low molecular weight $(<1000)$. Thus it was possible that the decrease of antioxidant activity utilizing higher concentration of enzyme in prolonged incubation time was due to the production of smaller peptides as the result of extensive enzymatic hydrolysis. It was also convinced by the result of Herpandi (2013), Foh et al. (2010) and Ovissipour et al. (2011) which also found that even using endoprotease enzymes, it could also produce low molecular weight protein if carried out on longer time of hydrolysis.
Further, since papain also could react diversely from complex to simple protein, it is reasonable that the longer the hydrolysis time, the extensive hydrolysis process tend to hydrolyze previously liberated peptide into smaller and lower molecular weight compound that resulted in low antioxidant activity eventhough resulted in higher amount of liberated protein. Our Pearson correlation analysis also showed that there was no significant correlation between protein content with the antioxidant activity of SCG ( $>0.05)$.

\section{CONCLUSION}

The extraction of protein and antioxidative compound from spent coffee ground has been successfully carried out by means of protein hydrolysis utilizing papapin. The result showed that the spent coffee ground could be utilized further into antioxidative protein source since it could extract up to $67.38 \%$ of the protein and its hydrolysate also possess quite high antioxidant activity. The use of crude papain had proven to be effective to hydrolyze the spent coffee ground with its optimum concentration of $6 \%$ and 2 hours incubation time.

\section{ACKNOWLEDGEMENT}

The author would like to express his gratitude to the technicians in Post-harvest Laboratory of ICCRI (Mrs. Ninik and Fitratin) and anonymous reviewer for their contribution to the perfection of this paper.

\section{REFERENCES}

Amarowicz, R. (2008). Antioxidant activity of protein hydrolysates. European Journal of Lipid Science and Technology, $110,489-490$

Apiwatanapiwat, W.; P. Vaithanomsat; P. Somkliang $\&$ T. Malapant (2009). Optimization of 
protein hydrolysate production process from jathropa curcas cake. WASET International Journal of Agricultural and Biosystem Engineering, 3, 250-253.

BSN. (2014). SNI 3747-2013 Kakao Bubuk. Badan Standardisasi Nasional, Jakarta, Indonesia.

Campos-Vega, R; G. Loarca-Pina; H.A. VergaraCastaneda \& B. Dave Oomah (2015) Spent coffee grounds: A review on current research and future prospects. Food Science and Technology, 45, 24-36.

Centenaro, G.S.; M.S. Mellado \& C. PrenticeHernandez (2011). Antioxidant activity of protein hydrolysates of fish and chicken bones. Advance Journal of Food Science and Technology, 3, 280-288.

Chapot-Chartier, M.P \& M.Y. Mistou (2004). PepC aminopeptidase of lactic acid bacteria. p. 1202-1204. In: Handbook of Proteolytic Enzymes. A.J. Barrett, N.D. Rawlings \& J.F. Woessner (Eds). Elsevier, London.

Cruz, M.V.; A. Paiva; P. Lisboa; F. Freitas; V.D. Alves \& P. Simoes (2014). Production of polyhydroxyalkanoates from spent coffee grounds oil obtained by supercritical fluid extraction technology. Bioresource Technology, 157, 360-363.

Dudley, E.G. \& J.L. Steele (2004). Dipeptidase DA. p. 2052-2053. In: Handbook of Proteolytic Enzymes. A.J. Barrett, N.D. Rawlings \& J.F. Woessner (Eds). Elsevier, London.

Esquivel, P. \& V.M. Jimenez (2012). Functional properties of coffee and coffee byproducts. Food Research International, 46, 488-495.

Febrianto, N.A. (2013). Hidrolisat protein asal bungkil kakao dan ampas kopi. Warta Pusat Penelitian Kopi dan Kakao Indonesia, 25, 20-23.

Foh, M.B.K.; I. Amadou; B. Foh; M.T. Kamara \& W. Xia (2010). Functionality and antioxidant properties of tilapia (Oreochromis niloticus) as influenced by the degree of hydrolysis. International Journal of Molecular Sciences, 11, 1851-1869.
Gallegos-Tintore, S.; C.T. Fuentes; J.S. Feria; M. Alaiz; J.G. Calle; A.L.M. Ayala; L.C. Guerrero \& J Vioque (2011). Antioxidant and chelating activity of Jatropa curcas L. protein hydrolysates. Journal of the Science of Food and Agriculture, $91,1618-1624$.

Graf, L.; L. Szilagy \& I. Venekei (2004). Chymotrypsin. p. 1495-1501. In: Handbook of Proteolytic Enzymes, A.J. Barrett, N.D. Rawlings \& J.F. Woessner (Eds). Elsevier, London.

Hamada, J.S. (2000). Characterization and functional properties of rice bran proteins modified by commercial exoproteases and endoproteases. Journal of Food Science, 65, 305-310.

Haslaniza, H.; M.Y. Maskat; W.M.W. Aida \& S. Mamot (2010). The effects of enzyme concentration, temperature and incubation time on nitrogen content and degree of hydrolysis of protein precipitate from cockle (Anadara granosa) meat wash water. International Food Research Journal, 17, 147-152.

Herpandi (2013). Enzymatic Hydrolysis of Tuna byproducts: Physico-Chemical Characteristics, Digestibility and Antioxidative Properties of the Hydrolysate. PhD Thesis. Universiti Sains Malaysia, Penang, Malaysia.

Herpandi; A Rosma; W.A.W. Nadiah; N.A. Febrianto $\&$ N. Huda (2017). Optimization of enzymatic hydrolysis of skipjack tuna by-product using protamex: a response surface approach. Journal of Fundamental and Applied Sciences, 9, 845-860.

Hoyle, N.T. \& J.H. Merrit (1994). Quality of fish protein hydrolysates from herring (Clupea harengus). Journal of Food Science, 59, 76-79.

Je, J.Y.; P.J. Park \& S.K. Kim (2005). Antioxidant activity of a peptide isolated from Alaska pollack (Theragra chalcogramma) frame protein hydrolysate. Food Research International, 38, 45-50.

Je, J.Y.; Z.J. Qian; H.G. Byun \& S.K. Kim (2007). Purification and characterization of an antioxidant peptide obtained from 
tuna backbone protein by enzymatic hydrolysis. Process Biochemistry, 42, 840-846.

Jun, S.Y.; P.J. Park; W. Jung \& S.K. Kim (2004). Purification and characterization of an antioxidative peptide from enzymatic hydrolysate of yellowfin sole (Limanda aspera) frame protein. European Food Research and Technology, 219, 20-26.

Kalantzakis G.; G. Blekas; K. Pegklidou \& D. Boskou (2006). Stability and radical-scavenging activity of heated olive oil and other vegetable oils. European Journal of Lipid Science and Technology, 108, 329-335

Karamac, M.; A Kosinka-Cagnazzo \& A. Kulcyk (2016). Use of different proteases to obtain flaxseed protein hydrolysates with antioxidant activity. International Journal of Molecular Sciences, 17, 1-13

Murthy, P.S. \& M.N. Naidu (2012). Recovery of phenolic antioxidants and functional compounds from coffee industry byproducts. Food and Bioprocess Technology, 5, 897-903.

Ovissipour, M.; A.A. Kenari; A. Motamedzadegan; B. Rasco \& R.M. Nazari. (2011). Optimization of protein recovery during hydrolysis of yellowfin tuna (Thunnus albacares) visceral proteins. Journal of Aquatic Food Product Technology, 20, 148-159.

Pasupuleti, V.K. \& S. Braun (2010). State of the art manufacturing of protein hydrolysates. Protein Hydrolysates in Biotechnology, 11-32.

Rawlings, N.D.; F.R. Morton \& A.J. Barrett. (2007). An introduction to peptidases and the MEROPS database. p. 161-179. In: Industrial Enzymes-Structure, Function and Applications. J. Polaina \& A.P. MacCabe (Eds). Springer, Dordrecth, Netherlands.

Sani, M.T. (2008). Penambahan Natrium Bisulfit pada Kualitas Enzim Papain dari Getah Pepaya Secara MCU. Unesa University Press, Surabaya, Indonesia.

Shahidi, F. \& Y. Zhong (2008). Bioactive peptides. Journal of American Organization of
Analytical Chemistry International, 91,914-931.

Simpsona, B.K.; G. Nayeria; V. Yaylayana \& I.N.A. Ashieb (1998). Enzymatic hydrolysis of shrimp meat. Food Chemistry, $1-2,131-138$.

Sudarmadji S.; B. Haryono \& Suhardi (1997). Prosedur Analisa untuk Bahan Makanan dan Pertanian. Liberty, Jogjakarta, Indonesia.

Tsuge, H.; T. Nishimura; Y. Tada; T. Asao; D. Turk; V. Turk, \& N. Katunuma (1999). Inhibition mechanism of cathepsin L-specific inhibitors based on the crystal structure of papain CLIK148 complex. Biochemical and Biophysical Research Communications, 266, 411-416.

Uhlig, H. (1998). Industrial Enzymes and their Applications. 1st Edn., John Wiley and Sons, New York.

Viera, G.H.F.; A.M. Martin; S. Saker-Sampaiao; S. Omar \& C.F. Goncalves (1995). Studies on the enzymatic hydrolysis of Brazilian lobster (Panulirus spp.) processing wastes. Journal Science Food Agricultural, 69, 61-65.

Wu W.A.; N.S. Hettiarachchy \& M. Qi (1998). Hydrophobicity, solubility, and emulsifying properties of soy protein peptides prepared by papain modification and ultrafiltration. Journal of American Oil Chemist Society, 75, 845-850.

Zarei, M.; A. Ebrahimpour; A. Abdul-Hamid; F. Anwar \& N. Saari (2012). Production of defatted palm kernel cake protein hydrolysate as a valuable source of natural antioxidants. International Journal of Molecular Sciences, 13, 8097-8111.

Zhang, M.; T.H. Mu; Y.B. Wang \& M.J. Sun (2012). Evaluation of free radical-scavenging activities of sweet potato protein and its hydrolysates as affected by single and combination of enzyme systems. International Journal of Food Science and Technology, 47, 696-702.

$$
* * 0 * *
$$

